\title{
News and Announcements
}

\author{
First Use of CATVLIB Network: \\ American Red Cross \\ Satellite Telecast
}

On May 21, 1981, the American Red Cross celebrated their one-hundredth birthday by ending their annual conference in Washington, D.C., with a special twohour nationwide satellite telecast. The PSSC coordinated distribution of the telecast, which originated from Constitution Hall in Washington, D.C., from $10 \mathrm{a} . \mathrm{m}$. to noon. The program was carried on SATCOM I, transponder 16 (Appalachian Community Service Network), and made available to all cable systems able to receive this transponder. Those areas not able to schedule the live program were offered a satellite-transmitted taped feed later in the day. The American Red Cross had encouraged all its local chapters to initiate program reception in their communities by approaching the local cable system about carrying the event.

Since the American Red Cross was offering a free program and trying to saturate as much of the United States as possible, use of the CATVLIB network in conjunction with this telecast was appropriate. PSSC contacted 53 libraries in 23 states that were interested in assuming local coordination for bringing this event to their communities. As the local coordinator, the CATVLIBs' minimum responsibilities included alerting the cable systems to schedule receiving this program (if the local Red Cross chapter had not already approached the CATV) and contacting the local Red Cross chapter to offer the CATVLIBs' facilities for their group viewing and concomitant local celebration.

Of these fifty-three CATVLIBs, only seven could not participate because of technical problems. Schedule conflicts; lack of CATV, Red Cross, or community interest; and Red Cross alternative plans were the major factors in prohibiting twelve others from directly participating in hosting the satellite-transmitted program. The remaining thirty-four CATVLIBs did host community residents in their facilities.

Evaluation forms revealed a variety of degrees of CATVLIB participation in coordinating their first satellite event participation. Several CATVLIBs (though none came to the library for viewing) were instrumental in getting the program into the community and available to all local cable subscribers. Advance publicity, birthday cakes and refreshments, sing-alongs, taping for multiple showings, and joint library/ chapter pre- and postevent activities are but a few of the ways the individual CATVLIBs participated. All of the evaluation forms indicated that the CATVLIBs wanted to be contacted as a potential local site for future satellite events.

The following list names the fifty-three CATVLIBS that were initially contacted to be local coordinators for the Red Cross onehundredth birthday satellite telecast. Though not all were successful, CATVLIB made an effort to bring the program to its community.

\section{Colorado}

Boulder Public Library, Boulder

Connecticut

Thomaston Public Library, Thomaston

Florida

Tarpon Springs Public Library, Tarpon Springs

Georgia

Tri-County Regional Library, Rome Idaho

Pocatello Public Library, Pocatello

Illinois

Pekin Public Library, Pekin

Rockford Public Library, Rockford

Indiana

Fort Wayne Public Library, Fort Wayne

Monroe County Public Library, Bloomington 
Iowa

Kirkwood Community College

Telecommunications Center, Cedar

Rapids

Iowa City Public Library, Iowa City

Kansas

Abilene Public Library, Abilene

Newton Public Library, Newton

Kentucky

Lexington Public Library, Lexington

Louisville Public Library, Louisville

Camden-Carroll Library, Morehead State University, Morehead

Massachusetts

Greenfield Community College Library, Greenfield

South Hadley Library System, South Hadley

\section{Minnesota}

Anoka County Library, Fridley

Cloquet Public Library, Cloquet

Crow River Regional Library, Willmar

International Falls Public Library, International Falls

Minnesota Valley Regional Library, Mankato

Marshall-Lyon County Library System, Marshall

Western Plains Library System, Montevideo

Rochester Public Library, Rochester

St. Cloud Public Library, St. Cloud

Missouri

St. Charles City County Library, St. Peters

New Jersey

Burlington County College Library, Pemberton

New York

Albany Public Library, Albany

Amherst Public Library, Williamsville

Bethlehem Public Library, Delmar

Chautauqua-Cattaraugus Library System, Jamestown

Gates Public Library, Rochester

Mid-York Library System, Utica

Ridge Road Elementary School Library,

Horseheads

North Carolina

Davidson County Community College

$$
\text { Library, Lexington }
$$

Ohio

Greene County District Library, Xenia

Public Library of Columbus and Franklin

County, Columbus
University of Toledo Library, Toledo

Pennsylvania

Altoona Area Public Library, Altoona

Lancaster County Library, Lancaster

Monroeville Public Library, Monroeville

Tennessee

Memphis/Shelby County Public Library \& Information Center, Memphis

Utah

Merrill Library and Learning Resources

Program, Utah State University, Logan

Weber County Library, Ogden

Virginia

Arlington County Department of

Libraries, Arlington

Washington

Edmonds Community College Library, Lynnwood

Lynnwood Public Library, Lynnwood

Mountlake Terrace Public Library, Mountlake Terrace

Seattle Public Library, Seattle

Wisconsin

Middleton Public Library, Middleton

Nicolet College Learning Resource Center, Rhinelander

\section{Who's Who and What's What in Library Video and Cable}

For librarians interested in who is doing what in video in libraries, or in how to do it themselves, a guidebook has been published by the Video and Cable Communications Section of the Library and Information Technology Association. It is the 461-page Video and Cable Guidelines.

Edited by Leslie Chamberlin Burk and Roberto Esteves - two of the most active librarians in the video field-the book includes papers from Donald Sager, Kandy Brandt, Arlene Farber Sirkin, Anne Hollingsworth, and by Burk and Esteves. Among the topics covered are a description of the present operation, future plans, problems, and benefits of video in 250 libraries in the U.S. and Canada.

The book is spiral-bound and can be used conveniently as a manual for staff development programs. Its price is $\$ 9.75$.

For additional information, or to order copies (prepaid orders only, please), contact LITA, ALA, 50 E. Huron St., Chicago, IL 60611; (312)944-6780. 


\section{ELMIG Electronic Mail Arrives}

The "new arrival" to the library association family this summer is the Electronic Library Membership Initiative Group. ELMIG is an organization of individuals established to ensure that electronically delivered information remains accessible to the general public. ELMIG promotes participation and leadership in the remote electronic delivery of information by publicly supported libraries and nonprofit organizations.

The group's efforts are coordinated by Richard Sweeney, director of the Public Library of Columbus and Franklin County; Neal Kaske, director of OCLC's Office of Research; and Kenneth Dowlin, director of the Pikes Peak Library District.

The first founding goals of ELMIG are:

- Identifying services and information best suited for the remote electronic access to and delivery of information;

- Planning, funding, and developing working demonstrations of library electronic information services;

- Communicating the availability of electronic library services to the community;

- Informing the library profession of trends, specific events, and future directions in remote electronic delivery of information;

- Creating coalitions with organizations in allied fields of interest.

Organizers of ELMIG are working within ALA to foster interest in, and facilitate the needs of, the electronic library. ALA has established a membership initiative group to address the concerns of this group. The Electronic Library Membership Initiative Group will meet during the ALA Midwinter Meeting in Denver. Interested individuals are encouraged to attend the meeting scheduled for Monday, January 25,1982 , at 2 p.m. in Room $2 \mathrm{E}$ of the auditorium.

Interest in ELMIG/ELA has surfaced quickly. The membership group was formed in March, and gathered the 200 signatures needed for official recognition at the ALA Annual Conference in San Francisco. Some 150 people met at that conference to discuss topics of concern. They decided to continue these discussions at the
1982 Midwinter Meeting and plan for an ELMIG program to be presented at Philadelphia.

ELMIG aims to address the issues concerning the electronic library on a continuing basis through ongoing interaction of its members. To facilitate this interaction, ELMIG will use an electronic mail system. Further information on ELMIG and its members is available from Richard Sweeney at the Public Library of Columbus and Franklin County, 28 S. Hamilton Rd., Columbus, $\mathrm{OH} 43213$.

See page 317 for Subscriber Agreement Form.

\section{Heynen to Head \\ ARL Microform Project}

The Association of Research Libraries has hired Jeffrey Heynen to head a two-year program designed to improve bibliographic access to microform collections in American and Canadian libraries. The association has received $\$ 20,000$ from the Council on $\mathrm{Li}$ brary Resources to initiate the project, and additional funds are anticipated from other sources.

Heynen brings an extensive background in micrographics and publishing to the project as well as a long-standing commitment to improving the treatment, use, and bibliographic control of microforms in libraries. He has served as chair of the American Library Association's Reproduction of Library Materials Section, and was a participant in earlier groups that laid the foundation for the current ARL project. Currently president of Information Interchange Corporation, Heynen has held executive positions with Congressional Information Service, Greenwood Press, and Redgrave Information Resources. These positions have all included responsibility for the creation of large microform collections. Heynen holds memberships in numerous standards-making bodies, including the International Organization for Standardization (ISO), the American $\mathrm{Na}$ tional Standards Institute, and the National Micrographics Association, and is a lecturer at the University of Maryland College of Library and Information Services.

The ARL Microform Project is based upon a planning study conducted for the association by Richard Boss of Information 
Systems Consultants, Inc. Its purpose is to stimulate and coordinate the work of libraries, microform publishers, bibliographic utilities, and regional networks in providing bibliographic access to millions of monographic titles in microform that are now inadequately or insufficiently cataloged. Since the development of the plan during 1980, there has been keen interest both in the elements of the plan and in the cooperative efforts needed to achieve them. A number of libraries-both ARL and nonARL members-are planning to begin or are already entering catalog records for individual titles in microform sets into bibliographic databases. For example, three ARL libraries have recently been awarded grants under Title II-C of the Higher Education
Act, Strengthening Research Library Resources, to catalog major microform sets, entering the resulting records into one of the major utilities. All three librariesStanford University, University of Utah, and Indiana University - will be coordinating their efforts with the goals of the ARL program.

Key to these efforts, however, is coordination to ensure that national standards are accepted and followed, to distribute the work load so that as many sets as possible are covered and duplication of effort is avoided, and to ensure that the records are available to all libraries that want to use them. The ARL Microform Project will emphasize building on existing resources, coordinating efforts among the library and pub-

\section{SUBSCRIBER AGREEMENT \\ ELECTRONIC LIBRARY MEMBERSHIP INITIATIVE GROUP}

(ALA Member), applies for membership in the ELECTRONIC LIBRARY MEMBERSHIP INITIATIVE GROUP, electronic mail system, and states that:

\section{RECITALS:}

A. ELMIG is an association of individuals whose mission is to ensure that information delivered electronically remains accessible to the general public; and

B. ELMIG seeks to promote participation and leadership in remote electronic delivery of information by publicly supported libraries and nonprofit organizations.

NOW THEREFORE, the above Member and OCLC agree that:

1. Member will deposit with OCLC a $\$ 100$ contribution toward the cost of electronic mail service and attendant expenses for the first year of operation, which is to commence January 1,1982 . The Member recognizes that the initial Member contribution may not be sufficient to pay for a year of operation and agrees, when invoiced, to make additional payments of $\$ 100$, or other agreed upon sums, to OCLC for the continuation of service.

2. OCLC agrees that by accepting Member deposits, it will secure electronic mail service for the Members of ELMIG; and

2.1 Will place Member deposits in a separate ELMIG account from which OCLC will pay the cost of the electronic mail service, U.S. postal mailings, and any other expenses incurred in the administration of EMS.

2.2 Will provide a year-end accounting of contributions and expenditures to Members within a reasonable time after December 31, 1981, and each year-end thereafter.

\section{MEMBER:}

BY

TITLE

DATE 
lishing communities and the bibliographic utilities, and, where possible, facilitating cooperative projects already planned or under way.

Heynen will be assisted by an advisory committee composed of representatives of both ARL and non-ARL libraries, the major bibliographic utilities, and microform publishers. The ARL project will operate out of the office of Information Interchange Corporation, 503 11th St., SE, Washington, DC 20003; (202)544-0291. Libraries and publishers interested in participating in the project are urged to contact the project office.

\section{Nominations Sought for LITA Award}

Nominations are being sought for the Library and Information Technology Associ- ation's Award for Achievement.

The award is intended to recognize distinguished leadership, notable development or application of technology, superior accomplishments in research or education, or original contributions to the literature of the field.

The award may be given to an individual or to a small group of individuals working in collaboration. Organized institutions or parts of organized institutions are not eligible.

Nominations for the award may be made by any member of the American Library Association and should be submitted by January 15, 1982, to Hank Epstein, LITA Awards Committee Chairperson, 1992 Lemnos Dr., Costa Mesa, CA 92626.

\section{ARE THESE BOOKS ON YOUR SHELF?}

The Special Library Role in Networks: Proceedings of a Conference

Robert W. Gibson, Jr., ed. 296 p. 1980 ISBN $0-87111-279-5 \ldots \ldots \ldots \ldots \ldots \ldots \ldots \ldots \ldots \$ 10.50$

Reports on the current state of networking and presents a creative approach to special library involvement in network participation and management.

Special Libraries Special Issue on Information Technology and Special Libraries

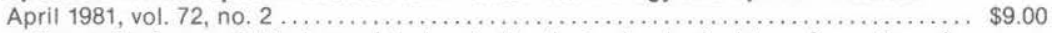

The entire issue of this journal is devoted to the technological transformation of

the information industry. Topics discussed are such advances as computer and

telecommunications components, software developments, linking, and modes of access to information systems.

Bibliographic Utilities: A Guide for the Special Librarian

James K. Webster, ed. 32 p. 1980 ISBN $0-87111-280-7 \ldots \ldots \ldots \ldots \ldots \ldots \ldots \ldots \ldots \ldots 3.75$

A comparative study of the services offered by the four major North American online bibliographic utilities.

Total \$

Send to:

Special Libraries Association

Order Department-Box JLA

235 Park Avenue South

New York, New York 10003

Date

Name

Organization

Street Address

City State Zip

New York City purchasers add $81 / 4 \%$ state and city sales tax.

New York State purchasers add appropriate state and local sales tax. 